\title{
Direct Electrochemical Synthesis and Characterization of Coordination Compounds of Copper(II) Chloride: Part - II
}

\author{
H. KAUR ${ }^{*}$ and A. KAUR \\ Department of Chemistry, Punjabi University, Patiala - 147002, Punjab, India \\ hk160777@gmail.com
}

Received 4 April 2014 / Accepted 21 April 2014

\begin{abstract}
Coordination compounds of $\mathrm{CuCl}_{2}$. L (where $\mathrm{L}=1,10$-phenanthroline or 2,2'bipyridyl) have been synthesized by electrolyzing the aqueous solution of hydrochloric acid and ligand at sacrificial copper anode and inert platinum cathode. The products isolated have been characterized by elemental analysis, infrared spectral data and $\mathrm{x}$ - ray crystallography. Current efficiencies of both these reactions are found to be quite high.
\end{abstract}

Keywords: Electrochemical synthesis, 1,10-Phenanthroline, 2,2'-Bipyridyl, Copper(II) chloride, Coordination compounds

\section{Introduction}

Electrochemical technique has been used as an integral tool for the synthesis of a variety of organic $^{1-6}$, inorganic ${ }^{7-10}$ and nanoparticles ${ }^{11,12}$. The important advantages of this technique include single step reactions, direct route, high product yield and cheap starting material. In continuation to our interest in synthetic inorganic chemistry ${ }^{13-17}$, we report in this communication the electrochemical synthesis of the coordination compounds of the copper(II) chloride.

\section{Experimental}

Water was purified by adding potassium permanganate and a pellet of potassium hydroxide and then was fractionally distilled. Rectified spirit was fractionally distilled. 1:1 mixture of conductivity water and rectified spirit was used as solvent in both these reactions. Other organic compounds were used as procured.

\section{Procedure and technique}

Electrolysis of solution of conductivity water - rectified spirit mix solvent (1:1) containing $2 \mathrm{~mL}$ of hydrochloric acid and $0.5 \mathrm{~g}$ of ligand (1,10-phenanthroline or 2,2'-bipyridyl) have been conducted at sacrificial copper anode $\left(2.0 \times 10 \times 0.2 \mathrm{~cm}^{3}\right)$ and inert platinum $\left(1 \times 1 \mathrm{~cm}^{2}\right)$ cathode in $\mathrm{H}$ - type pyrex glass cell. Potential across the electrodes was adjusted so that a current of $15 \mathrm{~mA}$ passed through the solution. Potassium chloride was used as supporting electrolyte in both these reactions. The electrolytic solution was stirred efficiently using magnetic stirrer. The electrolytic cell can be represented as: 


$$
\mathrm{Cu}_{(+)} \mid \mathrm{HCl}+\mathrm{L}+\mathrm{KCl}+\text { solvent } \mid \mathrm{Pt}_{(-)}
$$

Where $\mathrm{Cu}_{(+)}$and $\mathrm{Pt}_{(-)}$represent sacrificial copper anode and platinum cathode respectively and L represents 1,10-phenanthroline or 2,2'-bipyridyl. After electrolysis for three hours, reaction mixture from anode compartment was concentrated and was kept for a day. The coloured crystals were isolated.

Elemental analysis of $\mathrm{C}, \mathrm{H}$ and $\mathrm{N}$ were performed on elemental vario MICRO cube analyser. Copper contents in the products were determined volumetrically ${ }^{18}$. Infrared spectra were recorded as potassium bromide pellets on Perkin - Elmer spectrophotometer (RXI) in the region of $4000-450 \mathrm{~cm}^{-1}$. The relevant analytical data are given in Table 1.

Table 1. Electrochemical characteristics, analytical data, current efficiencies and other related data of electrolytic products of hydrochloric acid + ligand systems at copper anode. [Potential : $30 \mathrm{~V}$, current in coulombs : 162]

\begin{tabular}{|c|c|c|c|c|c|c|c|}
\hline \multirow{2}{*}{ System } & \multirow{2}{*}{ Product } & \multirow{2}{*}{ Colour } & \multicolumn{4}{|c|}{$\begin{array}{l}\text { Elemental analysis } \\
\text { Found (Calcd.) \% }\end{array}$} & \multirow{2}{*}{$\begin{array}{c}\text { Current } \\
\text { efficiency (gram } \\
\text { equivalent } \\
\text { Faraday }^{-1} \text { ) }\end{array}$} \\
\hline & & & $\mathrm{Cu}$ & $\mathrm{C}$ & $\mathrm{H}$ & $\mathrm{N}$ & \\
\hline $\begin{array}{l}\text { Hydrochloric } \\
\text { acid }+1,10- \\
\text { phenanthroline }\end{array}$ & $\begin{array}{c}\mathrm{CuCl}_{2} \\
\left(\mathrm{C}_{12} \mathrm{H}_{8} \mathrm{~N}_{2}\right)\end{array}$ & green & $\begin{array}{l}19.7 \\
(20.1)\end{array}$ & $\begin{array}{c}45.8 \\
(45.8)\end{array}$ & $\begin{array}{c}2.5 \\
(2.5)\end{array}$ & $\begin{array}{c}8.7 \\
(8.8)\end{array}$ & 0.92 \\
\hline $\begin{array}{l}\text { Hydrochloric } \\
\text { acid }+2,2 \text { '- } \\
\text { bipyridyl }\end{array}$ & $\begin{array}{c}\mathrm{CuCl}_{2} \\
\left(\mathrm{C}_{10} \mathrm{H}_{8} \mathrm{~N}_{2}\right)\end{array}$ & blue & $\begin{array}{l}20.8 \\
(21.8)\end{array}$ & $\begin{array}{c}41.2 \\
(41.3)\end{array}$ & $\begin{array}{c}2.5 \\
(2.7)\end{array}$ & $\begin{array}{c}8.9 \\
(9.6)\end{array}$ & 0.93 \\
\hline
\end{tabular}

Single crystal of $\left[\mathrm{CuCl}_{2} \mathrm{C}_{10} \mathrm{H}_{8} \mathrm{~N}_{2}\right]$ with approximate dimensions of $0.18 \times 0.09 \times$ $0.06 \mathrm{~mm}^{3}$ was mounted on a glass fiber and data were collected at $100(2) \mathrm{K}$ on a "Bruker SMART APEX" CCD diffractometer using graphite monochromatic Mo Ka radiation $(\lambda=0.71073 \AA)$. The linear absorption coefficients, scattering factors for the atoms, and the anomalous dispersion corrections were taken from the International Tables for X-ray Crystallography ${ }^{19}$. The data integration and reduction were carried out with SAINT ${ }^{20}$ software. Empirical absorption correction was applied to the collected reflections with $\mathrm{SADABS}^{21}$ and the space group was determined using XPREP ${ }^{22}$. The structure was solved by the direct methods using SHELXL- $97^{23}$ and refined on $\mathrm{F}^{2}$ by full-matrix least-squares using the SHELXL-97 program package ${ }^{24}$. All non-hydrogen atoms were refined anisotropically. In order to refine $\mathrm{H}$ atoms, these atoms attached to carbon atoms were positioned geometrically and treated as riding atoms using SHELXL default parameters. A summary of crystal data, experimental details and refinement result are listed in Table 2. Atomic coordinates of non-hydrogen atoms are given in Table 3. Efforts have done to collect the single crystal x- ray data of $\left[\mathrm{CuCl}_{2} \mathrm{C}_{12} \mathrm{H}_{8} \mathrm{~N}_{2}\right]$, but these crystals do not diffract.

\section{Results and Discussion}

The selected bond lengths and angles are listed in Table 4. The x-ray data analysis reveals that $\left[\mathrm{Cu}\right.$ (bipy) $\left.\mathrm{Cl}_{2}\right]$ unit exist as polymer (Figure 1) in which central copper ion is coordinated to both nitrogen donors from bidentate 2,2'-bipyridine ligand forming five membered chelating ring and $\mathrm{Cu}-\mathrm{N}$ bond length are 2.026(7) and 2.032(6) $\AA$. Each copper ion is covalently bonded to two chlorine anions and the central copper ion forms two four membered rings through chlorine bridging thus can be described as distorted octahedral. The bond lengths of $\mathrm{Cu}-\mathrm{Cl}$ are 2.273(2) and 2.65(2) $\AA$. The important bond lengths and bond angles are listed in Table 4. 
Table 2. Crystal data and structure refinement for $\mathrm{CuCl}_{2} \cdot \mathrm{C}_{10} \mathrm{H}_{8} \mathrm{~N}_{2}$

\begin{tabular}{|c|c|c|}
\hline Formula weight & 290.62 & \\
\hline Temperature & $100(2) \mathrm{K}$ & \\
\hline Wavelength & $0.71069 \AA$ & \\
\hline Crystal system & Triclinic & \\
\hline Space group & P-1 & \\
\hline Unit cell dimensions & $\begin{array}{l}\mathrm{a}=7.255(4) \AA \\
\mathrm{b}=8.992(3) \AA \\
\mathrm{c}=9.530(5) \AA\end{array}$ & $\begin{array}{l}\alpha=115.719(2)^{\circ} . \\
\beta=108.199(3)^{\circ} . \\
\gamma=94.142(5)^{\circ} .\end{array}$ \\
\hline Volume & $516.2(5) \AA^{3}$ & \\
\hline Z & 2 & \\
\hline Density (calculated) & $1.870 \mathrm{~g} / \mathrm{cm}^{3}$ & \\
\hline Absorption coefficient & $2.594 \mathrm{~mm}^{-1}$ & \\
\hline $\mathrm{F}(000)$ & 290 & \\
\hline Crystal size & $0.18 \times 0.09 \times 0.06 \mathrm{~mm}^{3}$ & \\
\hline Theta range for data collection & 2.57 to $26.00^{\circ}$ & \\
\hline Index ranges & $-8<=\mathrm{h}<=8,-11<=\mathrm{k}<=10,-10<=1<=11$ & \\
\hline Reflections collected & 2731 & \\
\hline Independent reflections & $1950[\mathrm{R}(\mathrm{int})=0.0607]$ & \\
\hline Completeness to theta $=26.00^{\circ}$ & $96.4 \%$ & \\
\hline Absorption correction & Empirical & \\
\hline Max. and min. transmission & 0.8599 and 0.6524 & \\
\hline Refinement method & Full-matrix least-squares on $\mathrm{F}^{2}$ & \\
\hline Data / restraints / parameters & $1950 / 0 / 136$ & \\
\hline Goodness-of-fit on $\mathrm{F}^{2}$ & 1.031 & \\
\hline Final $R$ indices $[\mathrm{I}>2 \operatorname{sigma}(\mathrm{I})]$ & $\mathrm{R} 1=0.1040, \mathrm{wR} 2=0.2508$ & \\
\hline $\mathrm{R}$ indices (all data) & $\mathrm{R} 1=0.1189, \mathrm{wR} 2=0.2835$ & \\
\hline Largest diff. peak and hole & 1.701 and -2.308 e. $\AA^{-3}$ & \\
\hline
\end{tabular}

Table 3. Atomic coordinates $\left(\times 10^{4}\right)$ and equivalent isotropic displacement parameters $\left(\AA^{2} \times 10^{3}\right)$ for $\mathrm{CuCl}_{2} \cdot \mathrm{C}_{10} \mathrm{H}_{8} \mathrm{~N}_{2}$. (U(eq) is defined as one third of the trace of the orthogonalized $\mathrm{U}^{\mathrm{ij}}$ tensor)

\begin{tabular}{lllll}
\hline Atom & \multicolumn{1}{c}{$\mathrm{x}$} & \multicolumn{1}{c}{$\mathrm{y}$} & \multicolumn{1}{c}{$\mathrm{z}$} & $\mathrm{U}(\mathrm{eq})$ \\
\hline $\mathrm{Cu}(1)$ & $7623(1)$ & $688(1)$ & $10(1)$ & $30(1)$ \\
$\mathrm{Cu}(2)$ & $5441(3)$ & $-1897(3)$ & $-1699(3)$ & $40(1)$ \\
$\mathrm{Cu}(1)$ & $9529(3)$ & $-213(3)$ & $1735(3)$ & $40(1)$ \\
$\mathrm{N}(1)$ & $9156(11)$ & $3155(9)$ & $1522(8)$ & $30(2)$ \\
$\mathrm{N}(2)$ & $6189(10)$ & $1708(8)$ & $1424(8)$ & $27(1)$ \\
$\mathrm{C}(4)$ & $9212(14)$ & $5968(11)$ & $1964(12)$ & $44(2)$ \\
$\mathrm{C}(6)$ & $6829(11)$ & $3440(10)$ & $-708(10)$ & $28(2)$ \\
$\mathrm{C}(2)$ & $11524(14)$ & $5519(12)$ & $4069(11)$ & $43(2)$ \\
$\mathrm{C}(7)$ & $6058(14)$ & $4303(13)$ & $-1529(13)$ & $40(2)$ \\
$\mathrm{C}(8)$ & $4571(14)$ & $3430(13)$ & $-3107(11)$ & $46(2)$ \\
$\mathrm{C}(10)$ & $4736(15)$ & $884(12)$ & $-2940(11)$ & $41(2)$ \\
$\mathrm{C}(9)$ & $3890(15)$ & $1727(15)$ & $-3829(12)$ & $50(2)$ \\
$\mathrm{C}(5)$ & $8454(13)$ & $4241(10)$ & $976(11)$ & $32(2)$ \\
$\mathrm{C}(1)$ & $10686(13)$ & $3809(12)$ & $3042(11)$ & $40(2)$ \\
$\mathrm{C}(3)$ & $10769(15)$ & $6627(12)$ & $3545(13)$ & $47(2)$ \\
\hline
\end{tabular}


Table 4. Bond lengths $[\AA]$ and angles $\left[{ }^{\circ}\right]$ for $\mathrm{CuCl}_{2} \cdot \mathrm{C}_{10} \mathrm{H}_{8} \mathrm{~N}_{2}$

\begin{tabular}{cccc}
\hline $\mathrm{Cu}(1)-\mathrm{N}(1)$ & $2.026(7)$ & $\mathrm{Cu}(1)-\mathrm{Cl}(2)$ & $2.265(2)$ \\
\hline $\mathrm{Cu}(1)-\mathrm{N}(2)$ & $2.032(6)$ & $\mathrm{Cu}(1)-\mathrm{Cl}(1)$ & $2.273(2)$ \\
$\mathrm{N}(1)-\mathrm{Cu}(1)-\mathrm{N}(2)$ & $80.4(3)$ & $\mathrm{N}(2)-\mathrm{Cu}(1)-\mathrm{Cl}(2)$ & $93.3(2)$ \\
$\mathrm{N}(1)-\mathrm{Cu}(1)-\mathrm{Cl}(2)$ & $170.3(2)$ & $\mathrm{N}(1)-\mathrm{Cu}(1)-\mathrm{Cl}(1)$ & $93.9(2)$ \\
$\mathrm{N}(2)-\mathrm{Cu}(1)-\mathrm{Cl}(1)$ & $173.6(2)$ & $\mathrm{Cl}(2)-\mathrm{Cu}(1)-\mathrm{Cl}(1)$ & $92.71(9)$ \\
\hline
\end{tabular}

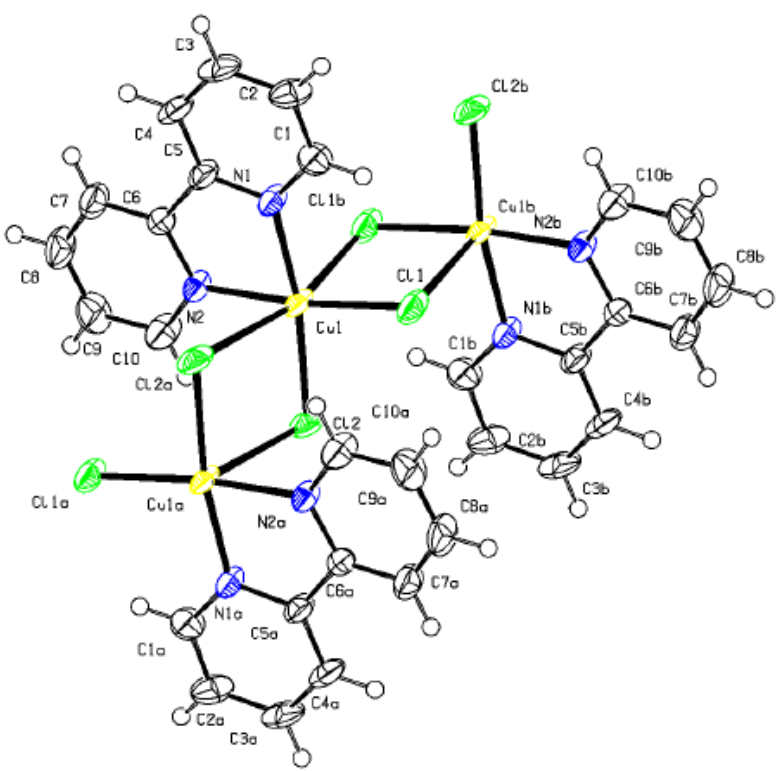

Figure 1. A perspective view of structure of $\mathrm{CuCl}_{2} \cdot \mathrm{C}_{10} \mathrm{H}_{8} \mathrm{~N}_{2}$

Both these products were soluble in acetonitrile, $N, N$-dimethyl formamide, dimethyl sulphoxide and acetone. Melting point determination of both the products shows that these products do not melt up to $300^{\circ} \mathrm{C}$, but decompose in temperature range of $150-250^{\circ} \mathrm{C}$. The decomposition of these products is indicated from the change in colour of the compounds in this temperature range. Elemental analysis data (Table 1) of both these products corresponds to $1: 2: 1$ stoichiometry of copper, chlorine and ligand.

Infrared spectra of both these products have been recorded in the region of $4000-450 \mathrm{~cm}^{-1}$. Examination of infrared data shows that the electrochemical products exhibit multiple bands in the regions of $1653-1057 \mathrm{~cm}^{-1}$ and $854-720 \mathrm{~cm}^{-1}$. Literature reveals that bands due to $v(\mathrm{C}=\mathrm{N}), \mathrm{v}(\mathrm{C}=\mathrm{C})$ bands and $\delta(\mathrm{C}-\mathrm{H})$, ring deformation bands of 1,10-phenanthroline and 2,2'bipyridyl $^{25,26}$ are present in the region of $1620-1217 \mathrm{~cm}^{-1}, 849-733 \mathrm{~cm}^{-1}$ and $1665-1065$ $\mathrm{cm}^{-1}, 755-740 \mathrm{~cm}^{-1}$ respectively. Multiple bands appearing in the region of $1653-1057 \mathrm{~cm}^{-1}$ in the present products thus can be assigned to $v(C=N)$ and $v(C=C)$ stretching vibrations and also $\delta(\mathrm{C}-\mathrm{H})$ mode and those in the region of $854-720 \mathrm{~cm}^{-1}$ can be assigned to ring deforming vibrations of the ligand molecules.

The infrared data thus supports the analytical data and confirm the attachment of ligand molecules to the electrochemical products of the present systems. Current efficiencies of both the systems have been determined, which was found to be very high. High current efficiencies of these systems indicate that reactions leading to the formation of coordination compounds of copper(II) chlorides are the predominant reactions of these systems. 


\section{Conclusion}

The electrochemical technique thus provides a direct route for the synthesis of anhydrous coordination compounds of copper(II) chloride, which otherwise involve multi-step process when prepared through traditional synthetic methods. In addition, the present method is single - pot, single step to carry out synthesis by using routine laboratory chemicals, apparatus and metals as regent at room temperature.

\section{Acknowledgement}

The authors express their gratitude to UGC, New Delhi for awarding the Maulana Azad National Fellowship (to Ms. Amandeep Kaur). We are grateful to acknowledge IIT, Kanpur for providing the facility to carry out X-ray crystallographic measurements.

\section{References}

1. Kim Tae-Hun and Park Su Moon, Electrochimica Acta, 2005, 50, 1461-1467.

2. Rehan H A, Polym Int., 2003, 52, 218 - 224.

3. Tsuchiya Youichi and Fujihara Hisashi, Electrochem., 2002, 70, 584 - 586.

4. Wadhawan Jay D, Marken Frank, Compton Richard G, Bull Steve D and Devis Stephen G, Chem Commun., 2001, 87- 88.

5. Lyalin B V and Petrosyan V A, Russian J Electrochem., 2013, 49(6), 497-529.

6. Senboku H, Takahasi M, Fukuhara T and Hara S, Chem Lett., 2007, 36, 228-229.

7. Padrares Antonio Sousa, Romero J, Garcia Vazquez Jose A, Duran M L, Casanova I and Sousa A, Dalton Trans., 2003, 1379-1388.

8. Tripathi V S, Bairwa K K, Mal D and Naik D B, J Electrochem Soc., 2014, 161(3), E34-E39.

9. Yuan Y, Yao J, Lin C, Zhang Y and Gu R, Synth React Inorg Met Org Nanometal Chem., 2005, 35, 385-390.

10. Yakhvarov D G, Ganushevich YU, Dobrynin A B, Kryvolapov D B, Litvinov I A and Sinyashin D G, Russ J Electrochem., 2009, 45(2), 139-144.

11. Ledesma-Garcia J, Arriaga L G, Chapman T W, Velazquez-Castillo R and Godinez L A, J Electrochem Soc., 2010, 157, E1-E5.

12. Singh Dinesh Pratap and Srivastava Onkar Nath, J Nanoscience Nanotech., 2009, 9, 5515-5522.

13. Banait J S, Singh Baljit and Kaur Harpreet, J Indian Chem Soc., 2011, 88, 641-646.

14. Banait J S, Singh Baljit and Kaur Harpreet, J Indian Chem Soc., 2010, 87, 261-264.

15. Kaur Harpreet, Banait J S and Singh Baljit, Asian J Chem., 2010, 3, 1073-1076.

16. Banait J S, Singh Baljit and Kaur Harpreet, Port Electrochim Acta, 2007, 25, 435-442.

17. Kaur Harpreet and Kaur Amandeep, J Indian Chem Soc., 2013, 90, 685.

18. Vogel's "Text Book of Quantitative Chemical Analysis", $5^{\text {th }}$ Edition, Longman group UK, Ltd., 1989, 393-394.

19. International Tables for X-Ray Crystallography, Kynoch Press, Vol. III, Birmingham, England, 1952.

20. SAINT, version 6.02, Bruker AXS, Madison, WI, 1999.

21. Sheldrick, GM SADABS: Empirical Absorption Correction Program, University of Gottingen, Gottingen, Germany, 1997.

22. XPREP, version 5.1; Siemens Industrial Automation Inc., Madison, WI, 1995.

23. Sheldrick, GM SHELXTL Reference Manual, version 5.1; Bruker AXS, Madison, WI, 1997. 
24. Sheldrick, GM SHELXL-97: Program for Crystal Structure Refinement, University of Gottingen, Gottingen, Germany, 1997.

25. Campos Vallette M M, Clavijo R E, Mendizabal F, Zamudio W, Baraona R and Diaz G, Vib Spect., 1996, 12, 37 - 44.

26. Lucile Arnaudet, Roland Bougon, Buu Ban, Pierrette Charpin, Jacques Isabey, Monique Lance, Martine Nierlich and Julien Vigner, Can J Chem., 1990, 68, 507-512 